\title{
Examining the relationship between corporate governance and bank performance in Bangladesh
}

\author{
J. Islam ${ }^{\mathrm{a}}$, M. Sathye $\mathrm{e}^{\mathrm{b}}$ and $\mathrm{H}$. Hu${ }^{\text {c* }}$

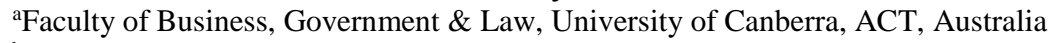 \\ ${ }^{b}$ Faculty of Business, Government \& Law, University of Canberra, ACT, Australia \\ ${ }^{\mathrm{c} S c h o o l ~ o f ~ E c o n o m i c s ~ a n d ~ M a n a g e m e n t, ~ W u h a n ~ U n i v e r s i t y, ~ H u b e i, ~ C h i n a ~}$ \\ *To whom all correspondence should be addressed \\ huizai1368@126.com
}

\begin{abstract}
Previous research has studied the impact of corporate governance on bank performance, but only a few aspects of the impact were reported. The present study develops a unique corporate governance index to provide a comprehensive measure of corporate governance and examines the relationship between this comprehensive measure and bank performance. We apply the Wilcoxon signed rank test to examine whether the introduction of the Code of Corporate Governance in Bangladesh has significantly promoted the improvement of corporate governance practices in Bangladeshi banks. Our results provide support for the hypothesis that corporate governance practices of Bangladeshi banks have been significantly improved since the introduction of the code. Further, the present study adopts regression analysis and reveals that the comprehensive measure of corporate governance is not significantly related to Bangladeshi banks' performance.
\end{abstract}

\section{Introduction}

In the literature, the question of whether strengthened corporate governance improves bank performance has received limited attention. However, policy makers and market participants assume the existence of a connection between corporate governance and bank performance. As pointed out by Love and Rachinsky (2007: 17), there are 'some significant, but economically unimportant relationships between governance and contemporaneous operating performance and even weaker links with the subsequent performance'.

While some prior studies have examined the relationship between bank performance and particular aspects of corporate governance, we did not come across a study that captures the relationship of bank performance and overall aspects of corporate governance (e.g., a comprehensive measure of corporate governance) except that of Larcker, Richardson and Tuna (2007: 963). Our study extends Larcker et al.'s (2007) work in the following respects. First, Larcker et al. (2007) focused on data of one year, which the authors identified as a major limitation of their study. We use data of four years, spanning a period from two years before to two years after the code's introduction. Second, Larcker et al.'s (2007) sample includes only U.S. firms and, as such, the results of the study are not generalizable. This study considers another subset to get the impact of comprehensive measures of corporate governance in Bangladesh banks and examines how these measures work in a setting outside of the United States - especially in an undeveloped country. Third, Larcker et al. (2007) excluded banks from their sample, while this study focuses exclusively on banks. Finally, our study provides a different case regarding the Bangladeshi banks, which have two types of ownership: state-owned and private.
The following reasons indicate the importance of this study. The global financial crisis, which resulted in the collapse of large financial institutions, brought into focus the need for better supervision and governance in banks internationally. Banks are corporations, and, as in other firms, investment value and financial credit usually depend on good governance (Caprio, Laeven \& Levine, 2007). Thus bank regulators have an interest in sound corporate governance mechanisms in banks from the perspective of financial system stability. Corporate governance in banks is also of interest to those businesses that depend on bank finance because the cost of funds in efficiently governed banks is usually lower (Polo, 2007).

Banks play a crucial role in undeveloped economies. Sound corporate governance of banks can also lower the investment risk of investors and help reduce the cost of financing, which will ultimately introduce a steady flow of foreign investment into the country (Farooque, Zijl, Dunstan \& Karim, 2007). Towards this end, in 2004, the Bangladesh Enterprise Institute (BEI) published the Code of Corporate Governance (CCG) for financial institutions among others. The obvious function of the CCG is to improve the general quality of corporate governance practices in Bangladesh. The CCG does this by codifying the principles and best practices of corporate governance, describing corporate governance structures and identifying optimal internal processes that corporations can take to improve corporate governance. In other words, the CCG provides a standard that can be used to measure financial institutions' progress towards best corporate governance practices.

Corporate governance in banks is particularly important for economic growth because economic development is dependent, to a large extent, on a well-functioning, stable and 
soundly managed banking system (Caprio \& Levine, 2002). Specifically, Bangladesh needs to make optimal use of domestic savings in banks to achieve economic growth. Furthermore, the predominance of banks as suppliers of funds is likely to stay due to the fact that people are relatively riskaverse, as well as the fact that stock exchanges in Bangladesh have not succeeded in gaining investors' confidence. The major reason is that deposits are mainly mobilized by the commercial banks in Bangladesh because their wide network and their predominance in the total banking sector (Bangladesh Bank, 2012).

Given the importance of banks and corporate governance in Bangladesh, it is imperative to promote corporate governance practices for banking organizations in this country (Khan, 2010). In this study, we have found the answers to these two research questions. The first research question is to assess whether the corporate governance practices in Bangladeshi banks have improved significantly since the introduction of the CCG. The second research question is to examine the relationship between the corporate governance of banks and the performance of Bangladeshi banks. Addressing the first research question, we create a comprehensive measure of banks' corporate governance based on the $\mathrm{CCG}$ and perform a content analysis of 30 major Bangladeshi banks' annual reports for four years. These years include two years before (2002 and 2003) and two years after (2005 and 2006) the introduction of the CCG in 2004. We evaluated the banks' compliance with the CCG by scoring each element of corporate governance in the $\mathrm{CCG}$, which enabled us to use a non-parametric difference test, the Wilcoxon signed rank test, to answer our first research question. For the second research question, the present study uses multiple regression to find the answer.

The rest of the paper proceeds as follows. The next section presents an overview of the banking industry in Bangladesh. The third section reviews previous literature and develops the hypotheses to be tested. The fourth section outlines the data collection and analysis methods used in this study. Our results are presented in the fifth section. Following the discussion and implications in the sixth section, the final section concludes the paper.

\section{Literature review and hypotheses development}

In the area of corporate governance practices of banks, three strands of literature are found. The first strand focuses on how corporate governance practices of banks differ from those of non-banking firms (e.g. Prowse, 1997; Furfine, 2001; Morgan, 2002; Macey \& O'Hara, 2003; Basel Committee on Bank Supervision, 2005). Furfine (2001) suggested that separate analysis of corporate governance of banks is needed. Although information asymmetries plague all industries in varying degrees, information asymmetries in the banking sector are becoming more serious. Given the important financial intermediation role of banking organizations in the economy, the Basel Committee on Banking Supervision (BCBS, 2005) asserted that corporate governance was more important for banking organizations than for other corporations.

The second strand of literature looks at how better governance practices in banks can help economic growth and financial development (e.g. Levine, 1997; Bushman \& Smith, 2003). For instance, Bushman and Smith (2003) presented a framework that identifies the channels through which information disclosure in the financial sector affects investments, productivity and added value of firms. It can be summarized from the study that there is a significant relationship between disclosure regimes in banking sector and economic outcomes.

The third strand is concerned with the impact of corporate governance practices on the performance and efficiency of banks (e.g. Jensen \& Meckling, 1976; Williamson, 1985; Hovey, Li \& Naughton, 2003; Berger, Clarke, Cull, Klapper \& Udell, 2005; Andres \& Vallelado 2008). This strand has its origin in agency theory.

The present study draws on the third strand of literature, including the agency theory advanced by Jensen and Meckling (1976). This theory postulates that the separation of ownership and management in corporations results in agency costs. These costs arise because managers may not act in the best interests of shareholders. To reduce the friction between ownership and management, an efficient corporate governance structure is often recommended.

In the literature, some research studies found that reforms in corporate governance promote the practices of corporate governance in firms (e.g. Jesover \& Kirkpatrick, 2005; Chen Li \& Shapiro, 2011). Chen et al. (2011) indicated that, on average, firms that have adopted corporate governance practices according to the Organization for Economic Cooperation and Development (OECD) principles have significantly improved corporate governance practices. The OECD corporate governance principles, which are an international benchmark for corporate governance, reflect a global consensus regarding the critical importance of sound corporate governance (Jesover \& Kirkpatrick, 2005). The CCG was developed with intensive consultation with the OECD corporate governance principles combined with the situation and specifics of Bangladesh (BEI, 2004). Based on a consideration of the above, it is argued that the CCG, which draws on the OECD principles of corporate governance, will improve corporate governance practices in Bangladeshi banks:

\section{Hypothesis 1: Corporate governance practices in Bangladeshi banks have undergone significant improvement since the introduction of the CCG.}

The relationship between corporate governance and operating performance of non-financial firms has been investigated extensively. For instance, in a U.S. study, Larcker, Richardson and Tuna (2005: 3) reported a positive relationship between the operating performance of firms and corporate governance. Hovey et al. (2003) investigated the relationship between firms' performance and corporate 
governance in China. The study found that one aspect of corporate governance, namely legal persons' shareholdings, is positively related to firms' performance. Filatotchev, Lien and Piesse (2005) and $\mathrm{Hu}$ and Sathye (2015) indicated that board members' financial interests and board independence have a positive influence on corporate performance. Bauwhede (2009: 497) found a positive association between the operating performance of European firms (FTSE Eurotop 300 index) and the extent of compliance with an international standard of best corporate governance practices. This standard was established by the International Corporate Governance Network and the OECD. In a more recent study, Shan and McIver (2011: 301) suggested that concentration of ownership is generally associated with poorer financial performance.

Moreover, a few studies have examined the link between bank performance and corporate governance. Williams and Nguyen (2005: 2119) investigated the impact of bank governance on bank performance for a group of commercial banks in Southeast Asian countries. The study reported that privatization, rather than other aspects of corporate governance, was a primary driver of performance. In the context of community banks, Spong and Sullivan (2007) examined the relationship between bank performance and the bank board members' financial interest in these banks, as well as between bank performance and managerial ownership. The study found that the ownership stake of hired managers, which is an aspect of corporate governance, helps to improve community bank performance. Andres and Vallelado (2008: 2570) examined the relationship between one aspect of corporate governance (board size and composition) and bank performance in six OECD countries. They found an inverted U-shaped relationship between bank performance and board composition. Further, they also found an inverted U-shaped relation between the proportion of outsiders and bank value which might be driving the relation between performance and board size.

Besides corporate governance, some prior studies indicated that several other factors affect bank performance. These factors mainly include bank ownership structure, the level of credit risk, bank's size and bank's efficiency. First, with regard to bank ownership structure, Berger et al. (2005), Lannotta, Nocera \& Sironi (2007), Nocera, Lannotta and Sironi (2007) and Lin and Zhang (2009) found that stateowned banks performed poorly. Williams and Nguyen (2005) and Yao, Jiang, Feng and Willenbockel (2007) indicated that non-state-owned banks had better performance than did stateowned banks. Second, for bank credit risk, most research studies revealed that credit risk could jeopardize the financial performance of banks (Herring, 1999). Third, for bank size, some studies suggested that larger banks do not always have better financial performance (e.g. Tarawneh, 2006). Likewise, some other studies found that the performance of large banks is negatively related to scales (e.g. Short, 1979; Miller \& Noulas, 1996; Kosmidou \& Zopounidis, 2008). Finally, most studies found significant relationships between bank efficiency and bank performance.

In this study, the focus is on the comprehensive measure of a bank's corporate governance and bank performance. Based on review of the literature, the following hypothesis summarizing the relationship between the comprehensive measure of corporate governance in banks and performance of banks is proposed:

Hypothesis 2: There is a significant positive relationship between the comprehensive measure of a bank's corporate governance and bank performance.

\section{Data collection and analysis method}

There are currently 38 scheduled domestic banks in Bangladesh. This study focuses on 30 of these banks which have available annual reports for all the four years within our study's timescale. To determine whether the corporate governance practices of banks in Bangladesh have significant improvement after the introduction of the CCG, the present study adopted the following procedures.

Annual reports accessed from the Global Mint Database were examined for the two years prior to and two years after 2004 (the year in which the CCG was introduced). The CCG has 99 elements. According to the information available in the banks' annual reports, each of the 99 corporate governance elements in the CCG was scored respectively on a scale of four to zero for each bank and each year separately. The method used is in line with the scoring system OECD used to assess various countries' compliance with the OECD principles of corporate governance (Abu-Tapanjeh, 2009). The maximum score for each element was four, which represented full compliance with the element. Great compliance with the element, which is significantly higher than the average level, was scored three; partial compliance was scored two; little compliance, which is significantly lower than the average level, was scored one; and no compliance was scored zero. Accordingly, the maximum score a bank could obtain for full compliance with the CCG was $396(=4 * 99)$. The total compliance scores of each of the 30 banks for the four years surrounding the issue of the CCG are listed in Table 1 below: 
Table 1: Total score of compliance with the CCG by each of the banks in the sample

\begin{tabular}{|c|c|c|c|c|c|c|c|c|c|}
\hline \multirow{3}{*}{$\begin{array}{c}\text { Bank } \\
\text { No. }\end{array}$} & \multicolumn{4}{|c|}{ CCG compliance score } & \multirow{3}{*}{$\begin{array}{c}\text { Bank } \\
\text { No. }\end{array}$} & \multicolumn{4}{|c|}{ CCG compliance score } \\
\hline & \multicolumn{2}{|c|}{ Before 2004} & \multicolumn{2}{|c|}{ After 2004} & & \multicolumn{2}{|c|}{ Before 2004} & \multicolumn{2}{|c|}{ After 2004} \\
\hline & 2002 & 2003 & 2005 & 2006 & & 2002 & 2003 & 2005 & 2006 \\
\hline 1 & 143 & 157 & 201 & 228 & 16 & 140 & 144 & 113 & 116 \\
\hline 2 & 121 & 119 & 162 & 167 & 17 & 89 & 95 & 148 & 142 \\
\hline 3 & 100 & 110 & 122 & 130 & 18 & 93 & 95 & 141 & 151 \\
\hline 4 & 98 & 103 & 165 & 177 & 19 & 120 & 135 & 148 & 153 \\
\hline 5 & 100 & 96 & 201 & 213 & 20 & 61 & 65 & 137 & 151 \\
\hline 6 & 111 & 114 & 144 & 150 & 21 & 36 & 48 & 169 & 168 \\
\hline 7 & 33 & 43 & 138 & 168 & 22 & 45 & 73 & 114 & 117 \\
\hline 8 & 94 & 101 & 161 & 163 & 23 & 74 & 98 & 147 & 151 \\
\hline 9 & 102 & 106 & 209 & 241 & 24 & 71 & 80 & 134 & 132 \\
\hline 10 & 91 & 99 & 161 & 165 & 25 & 97 & 103 & 163 & 166 \\
\hline 11 & 97 & 102 & 133 & 137 & 26 & 106 & 110 & 143 & 157 \\
\hline 12 & 71 & 79 & 149 & 165 & 27 & 73 & 84 & 188 & 198 \\
\hline 13 & 94 & 97 & 220 & 230 & 28 & 104 & 101 & 172 & 197 \\
\hline 14 & 177 & 169 & 163 & 200 & 29 & 110 & 108 & 199 & 201 \\
\hline 15 & 39 & 69 & 73 & 76 & 30 & 97 & 128 & 159 & 170 \\
\hline
\end{tabular}

A non-parametric difference test (Wilcoxon signed rank test) was used to assess whether the corporate governance practices in banks improved after the introduction of the CCG. To assess the impact of corporate governance on financial performance of Bangladeshi banks, a multiple regression analysis was used. The dependent variable, independent variable and control variables adopted in the analysis are listed below.

\section{Dependent variable}

Return on Assets (ROA): This study uses ROA to measure the financial performance of banks based on a large number of prior studies such as Altman, Haldeman and Narayanan (1977), Wilkins (1997) and Bauwhede (2009) that have used ROA to measure corporate financial performance. Additionally Barber and Lyon (1996) and Core, Guay and Rusticus (2006) argued that ROA is less affected by discretionary items than other performance measures such as net profit margin and return on equity.

\section{Independent variable}

Corporate Governance Compliance Score (Score): The total score achieved by each of the banks has been used as the measure of bank compliance with the CCG (see Table 1). In the literature, better corporate governance leads to better financial performance (e.g. Drobetz, Schillhofer \& Zimmermann, 2004; Klapper \& Love 2004; Love \& Rachinsky, 2007; Bauwhede, 2009). Accordingly, we expect to find a positive relationship between these two variables.

\section{Control variables}

Ownership: The present study identifies bank ownership structure by distinguishing state-owned banks (SOBs) from non-state-owned or private banks (NSOBs). Prior empirical studies have revealed that ownership structure affects bank performance. Berger et al. (2005), Lannotta et al. (2007), Nocera et al. (2007) and Lin and Zhang (2009) identified that state-owned banks perform poorly. Williams and Nguyen
(2005) indicated that private ownership of banks is associated with profit efficiency and improved productivity. Yao et al. (2007) investigated the effects of ownership structure on efficiency of Chinese domestic banks and found that NSOBs are more efficient than SOBs.

Risk: There is a trade-off between risk and return (performance). Higher risk is expected to lead to higher return, but higher risk can also make the bank vulnerable to failure. As credit risk is the most important risk faced by banks, the provision for bad and doubtful debts was used as a proxy for risk. Some other studies, such as that of Fan-fah and Nasir (2008), have done the same. Most research studies revealed that credit risk might jeopardize the financial performance of banks (Herring, 1999).

Size of Bank (Size): Total assets have commonly been used in prior studies to measure the size of a bank. However, banks with higher total assets have not always performed financially better (Tarawneh, 2006). Some prior studies have found that small banks tend to have scale economies, whereas the performance of large banks is negatively related to scales (Short, 1979; Miller \& Noulas, 1996; Kosmidou \& Zopounidis, 2008). The a priori relationship between size and financial performance is therefore indeterminate.

Efficiency: Efficiency of banks can make a tremendous impact on financial performance. Efficiency was measured using the bank's cost-to-income ratio - a ratio commonly used by banks to measure operational efficiency. Higher costto-income ratios are expected to inversely influence financial performance, as measured by return on assets. Accordingly, an inverse relationship is expected between the efficiency variable and bank performance.

All the variables used in this study, their measurements and signs expected a priori, are shown in Table 2. 
Table 2. Measurement and a priori sign of variables used in the model

\begin{tabular}{lll}
\hline \multicolumn{1}{c}{ Variables } & Measurements & A priori sign \\
\hline Dependent Variable & & \\
\hline Performance & ROA = Net Profit/Average Assets & \\
\hline Independent Variable & & Positive \\
\hline Score & Total score of bank's compliance with the CCG & \\
\hline Control Variables & & Positive \\
\hline Ownership & Binary variable equals 1 if private sector bank, 0 otherwise. & Indeterminate \\
Risk & Provision for bad and doubtful debts & Indeterminate \\
Size & Total assets & Inverse \\
Efficiency & Cost-to-income ratio & \\
\hline
\end{tabular}

The relationship between the dependent and independent variables is captured by the following economic model:

$$
\begin{aligned}
& \text { Performance } \\
& =f(\text { Ownership, risk, size, score, efficiency })
\end{aligned}
$$

The econometric model would take the following form:

$$
\begin{aligned}
& \text { ROA }=\alpha+\beta_{1} \text { Ownership }+\beta_{2} \text { Risk }+ \\
& \beta_{3} \text { Size }+\beta_{4} \text { Score }+\beta_{5} \text { Efficiency }+\varepsilon
\end{aligned}
$$

\section{Results}

To answer the first research question regarding whether corporate governance practices in banks improved significantly after introduction of the CCG, the Wilcoxon

\begin{tabular}{|c|c|c|c|c|}
\hline \multicolumn{5}{|l|}{ Panel A. Ranks } \\
\hline & & Number & Mean Rank & Sum of Ranks \\
\hline \multirow{4}{*}{$\begin{array}{l}\text { Issuance of the Code/Compliance } \\
\text { with the CCG before Issuance of } \\
\text { the Code }\end{array}$} & Negative Ranks & $3^{\mathrm{a}}$ & 6.33 & 19.00 \\
\hline & Positive Ranks & $57^{\mathrm{b}}$ & 31.77 & 1811.00 \\
\hline & Ties & $0^{c}$ & & \\
\hline & Total & 60 & & \\
\hline \multicolumn{5}{|c|}{$\begin{array}{l}\text { Compliance with CCG after issuance < Compliance with CCG before issuance } \\
\text { Compliance with CCG after issuance }>\text { Compliance with CCG before issuance } \\
\text { Compliance with CCG after issuance }=\text { Compliance with CCG before issuance }\end{array}$} \\
\hline \multicolumn{5}{|l|}{ Panel B. Test statistics } \\
\hline \multicolumn{5}{|c|}{ Compliance with CCG after issuance/Compliance with CCG before issuance } \\
\hline $\mathrm{Z}$ & & & & \\
\hline Asymp. Sig. (2-tailed) & \multicolumn{4}{|c|}{$\begin{array}{c}-6.596^{\mathrm{d}} \\
0.000^{\mathrm{e}}\end{array}$} \\
\hline
\end{tabular}
signed rank test was used. Table 3 below illustrates the results of the Wilcoxon signed rank test.

\section{Table 3. Wilcoxon signed ranks test statistics}

As can be seen from Table 3, the significant level of the Wilcoxon signed ranks test, presented as Asymp. Sig. (2tailed), is less than 0.001 and there are more positive than negative ranks. The results of this test indicate that the corporate governance practices of banks in Bangladesh were improved significantly after the introduction of the CCG.

The second research question required that the impact of corporate governance compliance on bank performance in Bangladesh have to be assessed. For this purpose, multiple regression analysis using Equation (2) was performed.

Prior to running the multiple regression, exploratory data analysis procedures for regression analysis were performed. The results of diagnostic tests are as follows:
Co-linearity: Variance inflation factor values were less than 10 for all variables, confirming the absence of multi-colinearity.

Outliers: SPSS procedures with three-standard-deviation criteria for outliers were used. No outliers were found.

Linearity and normality: Quantile-Quantile plots did not reveal any issues with normality or linearity.

Heteroscedasticity: It was checked by using the GoldfieldQuandt test. The results did not suggest that heteroscedasticity was an issue.

Based on the results of diagnostic tests, the sample size and all variables in this study are suitable for multiple regression. The results of multiple regression are presented in Table 4. 
Table 4. Results of multiple regression

\begin{tabular}{|c|c|c|c|c|c|}
\hline \multicolumn{6}{|c|}{ Panel A. Coefficients ${ }^{\mathrm{a}}$} \\
\hline \multirow[t]{2}{*}{ Model } & \multicolumn{2}{|c|}{ Unstandardized Coefficients } & \multirow{2}{*}{$\begin{array}{c}\begin{array}{c}\text { Standardized } \\
\text { Coefficients }\end{array} \\
\text { Beta } \\
\end{array}$} & \multirow[t]{2}{*}{$\mathrm{t}$} & \multirow[t]{2}{*}{ Sig. } \\
\hline & B & Std. Error & & & \\
\hline (Constant) & 0.003 & 0.004 & & 0.950 & 0.344 \\
\hline Ownership & 0.008 & 0.003 & 0.302 & 2.589 & $0.011^{\mathrm{b}}$ \\
\hline Risk & $-3.331 \mathrm{E}-6$ & 0.000 & -0.416 & -4.770 & $0.000^{\mathrm{c}}$ \\
\hline Size & $1.137 \mathrm{E}-8$ & 0.000 & 0.052 & 0.399 & 0.690 \\
\hline Score & $2.074 \mathrm{E}-5$ & 0.000 & 0.103 & 1.346 & 0.181 \\
\hline Efficiency & -0.002 & 0.000 & -0.357 & -4.850 & $0.000^{c}$ \\
\hline
\end{tabular}

b. $\mathrm{p}<0.05$

c. $\mathrm{p}<0.001$

\begin{tabular}{cccc}
\hline Panel B. Model summary & & & \\
\hline R & R Square & Adjusted R Square & Std. Error of the Estimate \\
\hline $0.700^{\mathrm{d}}$ & 0.490 & 0.467 & 0.006 \\
\hline
\end{tabular}

d. Predictors: (Constant), Ownership, Risk, Size, Score, Efficiency.

\begin{tabular}{lcccc}
\hline Panel C. ANOVA ${ }^{\mathbf{e}, \mathbf{f}}$ & & & & \\
\hline Model & Sum of Squares & Degrees of Freedom & Mean Square & F \\
\hline Regression & 0.005 & 5 & 0.001 & $21 . .873$ \\
Residual & 0.005 & 114 & 0.000 & $0.000^{\mathrm{g}}$ \\
Total & 0.010 & 119 & & \\
\hline
\end{tabular}

e. Predictors: (Constant), Ownership, Risk, Size, Score, Efficiency.

f. Dependent Variable: Return on Assets

g. $\mathrm{p}<0.001$

As can be seen from Table 4, three variables (ownership, risk and efficiency) were found to be significant in multiple regression analysis; all control variables and independent variable had the desired signs. Further details of the regression analysis results are presented below.

The risk variable is negatively related to performance and is significant at the one per cent level. Such results fit quite well with other research. Miller and Noulas (1996) and Ramlall (2009) found a negative relationship between credit risk and profitability. An International Monetary Fund study (Flamini, McDonald \& Schumacher, 2009) in sub-Saharan Africa found a similar relationship between credit risk and performance.

The efficiency variable has a negative relationship with performance and is significant at the one per cent level. It means that, for Bangladeshi banks, a higher cost-to-income ratio results in poorer bank performance. This finding is consistent with the conclusion of KPMG's (2010) research study on Australian banks.

In addition, the ownership variable has a positive relationship with performance and is significant at the five per cent level. In the literature, many research studies have detected a significant relationship between ownership and bank performance. For instance, Berger et al. (2005), Lannotta et al. (2007) and Lin and Zhang (2009) found that NSOBs usually have better performance compared with SOBs.

The sign of the relationship between bank performance and the size variable is positive for this study. There is no significant relationship between these two variables. Prior studies, like those by Miller and Noulas (1996), Jiang, Tang, Law and Sze (2003) and Barros et al. (2007), found negative relationships. Other studies, such as those done by Sinkey (1992) and Staikouras and Wood (2003), found that the results are indeterminate, while Akhavein, Berger and Humphrey (1997) and Demirguc-Kunt and Maksimovic (1998) have found a positive relationship between size and profitability.

Importantly, the variable of our interest, namely the score of bank's corporate governance, has a positive relationship with bank performance, whereas the relationship is not significant. Consequently, it cannot indicate that better corporate governance has a significant, positive relationship with the performance of Bangladeshi banks.

\section{Discussion and implications}

The findings of the current study are important because the relationship between a comprehensive measure of corporate governance and bank performance has not been examined by prior studies. To our knowledge, prior studies usually examine the relationship between bank performance and only a few specific aspects of corporate governance. Accordingly, our study contributes new knowledge to the extant literature on corporate governance and financial performance of banks.

This study is unique because it has used a comprehensive measure of corporate governance based on the CCG and examined its relationship with bank performance in Bangladesh for the first time. The results of this study show that the corporate governance practices of banks in Bangladesh have been significantly improved since the 
introduction of the CCG. This study also reveals that the comprehensive measure of corporate governance, which includes all aspects of corporate governance, is positively related to Bangladeshi banks' performance. Nevertheless, the effect is not significant.

As a matter of fact, the relationship between corporate governance and bank performance has remained controversial. On the one hand, some aspects of corporate governance (exempli gratia: ownership stake of managers) are significantly related to bank performance; on the other hand, the improvement of a few other aspects of corporate governance (e.g. number of outside directors) does not have any significant effect on bank performance. Prior studies such as the one by Kim and Rasiah (2010), which examined specific aspects of corporate governance and bank performance, found a positive and significant relationship between these two variables. Spong and Sullivan (2007) examined certain aspects of corporate governance and their effects on bank performance, and found that the ownership stake of hired managers and significant financial interests of board members can have a positive impact on bank performance.

However, a few other studies found that not all aspects of bank corporate governance have a positive relationship with bank performance. For instance, Dahlquist and Robertsson (2001) and Choi and Hasan (2005) argued that the number of outside directors on the board did not have any significant effect on bank performance, but the presence of a foreign director on the board was significantly associated with bank return. As pointed out by Wei (2007), non-state-owned shareholding has no effect on corporate performance if nonstate-owned shareholders dominate firms. The study also revealed that some corporate governance measures, such as the proportion of independent directors and independent supervisory directors, size of the board, managers' incentives and audit committee, have no significant effect on company performance.

Consequently, a possible explanation for our findings is that the comprehensive measure of corporate governance in this study includes all aspects of corporate governance. The improvement of some aspects of corporate governance does not have any effect on bank performance, whereas some other aspects of corporate governance are significantly related to bank performance. In terms of the comprehensive measure of corporate governance, two groups of corporate governance' effects might be offset from each other.

The findings of the current study may have significant implications for regulatory authorities and policy makers. To enhance the corporate governance practices of banks in Bangladesh, introducing the CCG and relative guidance notes is a particularly important step. For undeveloped countries such as Bangladesh, the CCG remains powerful influences on the inclination and capacity of banks to engage in establishing corporate governance mechanisms. Against this background, it is necessary for policy makers in undeveloped countries to set out principles and best practices of sound corporate governance.
The findings of this study may also have important implications to bank management in Bangladesh. For instance, given the comprehensive measure of corporate governance being not significantly related to banks' performance, banks' senior management in Bangladesh should devote more attention to risk, ownership and efficiency factors.

\section{Conclusions}

The present study, firstly, examined whether the corporate governance practices of banks in Bangladesh improved significantly after introduction of the 2004 CCG in this country. The annual reports of 30 Bangladeshi banks, two years before and two years after the introduction of the CCG, were examined. A comprehensive index of corporate governance, which evaluated the corporate governance practices of each bank for those four years, was constructed. This index is a unique aspect of our study. The Wilcoxon signed rank test was adopted to check whether there was a significant difference in corporate governance practices for banks after the introduction of the CCG. The test results show that the corporate governance practices of Bangladeshi banks improved significantly after the introduction of the CCG.

Further, this study examined the relationship between the comprehensive index of corporate governance and bank performance. The risk, efficiency and ownership variables are significantly and positively related with bank performance. Conversely, the comprehensive measure of corporate governance is not significantly related to Bangladeshi banks' performance. We cannot conclude with evidence from Bangladeshi banks that better corporate governance leads to better financial performance of banks in an undeveloped country such as Bangladesh. These results could be attributed to the fact that improvement of some aspects of corporate governance does not have any significant effect on bank performance, whereas some other aspects of corporate governance are significantly related to bank performance. Hence, the comprehensive measure of corporate governance applied in our study, which is different from any particular aspect of corporate governance or a few aspects of corporate governance, could not be significantly related to bank performance. Based on our study, future research may use such a comprehensive index of corporate governance as was used in our study to examine the impact of corporate governance in different settings, including different legal, institutional and cultural regimes (Ahlstrom, 2010; Huang, Chen and Kao, 2012).

\section{References}

Abu-Tapanjeh, A.M. 2009. 'Corporate governance from the Islamic perspective: A comparative analysis with OECD principles', Critical Perspectives on Accounting, 20: 556-567.

Ahlstrom, D. 2010. 'Publishing in the Asia Pacific journal of management', Asia Pacific Journal of Management, 27(1): 1-8. 
Akhavein, J.D., Berger, A.N. \& Humphrey, D.B. 1997. 'The effects of megamergers on efficiency and prices: Evidence from a bank profit function', Review of Industrial Organization, 12: 95-139.

Altman, E.I., Haldeman, R.G. \& Narayanan, P. 1977. 'Zeta analysis: A new model to identify bankruptcy risk of corporations', Journal of Banking and Finance, 1: 29-54.

Andres, P. \& Vallelado, E. 2008. 'Corporate governance in banking: The role of the board of directors', Journal of Banking and Finance, 32: $2570-2580$.

Bangladesh Enterprise Institute (BEI). 2004. The Code of Corporate Governance for Bangladesh principle and guidelines for best practices in the private sector, financial institutions, state-owned enterprises and non-governmental organisations. Dhaka: Bangladesh Enterprise Institute.

Bangladesh Bank. 2012. Bank and Financial Institutions.

Available [online] http://www.bangladesh-bank.org/

Barber, B.M. \& Lyon, J.D. 1996. 'Detecting abnormal operating performance: The empirical power and specification of test statistics', Journal of Financial Economics, 41: 359-399.

Barros, C.P., Ferreira, C. \& Williams, J. 2007. 'Analysing the determinants of performance of best and worst European banks: A mixed logit approach', Journal of Banking and Finance, 31: 21892203.

Basel Committee on Banking Supervision (BCBS). 2005. Enhancing Corporate Governance for Banking Organisations. Switzerland: Bank for International Settlements.

Bauwhede, H.V. 2009. 'On the relation between corporate governance compliance and operating performance', Accounting and Business Research, 39: 497-513.

Berger, A.N., Clarke, G., Cull, R., Klapper, L.F. \& Udell, G. 2005. 'Corporate governance and bank performance: A joint analysis of the static, selection, and dynamic effects of domestic, foreign, and state ownership', Journal of Banking and Finance, 29: 2179-2221.

Bushman, R.M. \& Smith, A.J. 2003. 'Transparency, financial accounting information, and corporate governance', Federal Reserve Bank of New York Economic Policy Review, 9: 65-87.

Caprio, G. \& Levine, R. 2002. Corporate governance in finance: Concepts and international observations. In: Litan, R.E., Pomerleano, M., Sundararajan, V. (Eds.), Financial Sector Governance: The Roles of the Public and Private Sectors. Brookings Institution Press, Washington, DC, 17-50.

Caprio, G., Laeven, L. \& Levine, R. 2007. 'Governance and bank valuation', Journal of Financial Intermediation, 16: 584-617.

Core, J.E., Guay, W.R. \& Rusticus, T. 2006. 'Does weak governance cause weak stock returns? An examination of firm operating performance and investors' expectations', Joumal of Finance, 61: 655-687.

Chen, V.Z., Li, J. \& Shapiro, D.M. 2011. 'Are OECD-prescribed 'good corporate governance practices' really good in an emerging economy?', Asia Pacific Journal of Management, 28(1): 215-238.
Choi, S. \& Hasan, I. 2005. 'Ownership, governance, and bank performance: Korean experience', Financial Markets, Institutions and Instruments, 14(4), 215-242.

Dahlquist, M. \& Robertsson. G. 2001. 'Direct foreign ownership, institutional investors, and firm characteristics', Journal of Financial Economics, 59: 413-440.

Demirguc-Kunt, A. \& Maksimovic, V. 1998. 'Law, finance and firm growth', Journal of Finance, 53: 2107-2137.

Drobetz, W., Schillhofer, A. \& Zimmermann, H. 2004. ,Corporate governance and expected stock returns: Evidence from Germany', European Financial Management, 10: 267-293.

Fan-fah, C. \& Nasir, A. 2008. 'The effect of financial risks on the earnings response in Australia bank stocks', Journal of Money, Investment and Banking, 6: 17-26.

Farooque, O.A., Zijl, T.V., Dunstan, K. \& Karim, A.W. 2007. 'Corporate governance in Bangladesh: Link between ownership and financial performance', Corporate Governance: An International Review, 15: 1453-1468.

Filatotchev, I., Lien, Y. \& Piesse, J. 2005. 'Corporate governance and performance in publicly listed, family-controlled firms: Evidence from Taiwan', Asia Pacific Journal of Management, 22: 257-283.

Flamini, V., McDonald, C. \& Schumacher, L. 2009. The determinants of commercial bank profitability in Sub-Saharan Africa. Working Paper No. 09/15, International Monetary Fund Working Paper Series.

Furfine, C.H. 2001. 'Banks as monitors of other banks evidence from the overnight federal funds market', Journal of Business, 74: 33-57.

Herring, R.J. 1999. 'Credit risk and financial instability', Oxford Review of Economic Policy, 15: 63-79.

Hovey, M., Li, L. \& Naughton, T. 2003. 'The relationship between valuation and ownership of listed firms in China', Corporate Governance, 11: 112-122.

Hu, H., \& Sathye, M. 2015. 'Predicting financial distress in the Hong Kong Growth Enterprises Market from the perspective of financial sustainability'. Sustainability, 7: 1186-1200.

Huang, Y., Chen, A. \& Kao, L. 2012. 'Corporate governance in Taiwan: The non-monotonic relationship between family ownership and dividend policy', Asia Pacific Journal of Management, 29(1): $39-58$.

Jesover, F. \& Kirkpatrick, G. 2005. 'The revised OECD principles of corporate governance and their relevance to non-OECD countries', Corporate Governance: An International Review, 13(2): pp.127-36.

Jiang, G., Tang, N., Law, E. \& Sze, A. 2003. Determinants of bank profitability in Hong Kong. Hong Kong Monetary Authority Research Memorandum, September.

Jensen, M.C. \& Meckling, W.H. 1976. 'Theory of the firm managerial behaviour, agency costs and ownership structure', Journal of Financial Economics, 3: 305-360. 
Khan, H. 2010. 'The effect of corporate governance elements on corporate social responsibility (CSR) reporting: Empirical evidence from private commercial banks of Bangladesh', International Journal of Law and Management, 52: 82-109.

Kim, P.K. \& Rasiah, D. 2010. 'Relationship between corporate governance and bank performance in Malaysia during the pre and post Asian financial crisis', European Journal of Economics. Finance and Administrative Sciences, 21: 39-63.

Klapper, L.F. \& Love, I. 2004. 'Corporate governance, investor protection and performance in emerging markets', Journal of Corporate Finance, 10: 703-728.

Kosmidou, K. \& Zopounidis, C. 2008. 'Measurement of bank performance in Greece', South-Eastern Europe Journal of Economics, 6: 79-95.

KPMG. 2010. KPMG Financial Institutions Performance Survey. Sydney: KPMG.

Lannotta, G., Nocera, G. \& Sironi, A. 2007. 'Ownership structure, risk and performance in the European banking industry', Journal of Banking and Finance, 31: 2127-2149.

Larcker, D., Richardson, S. \& Tuna, I. 2005. Ratings add fire to the governance debate, Financial Times, 26 May.

Larcker, D., Richardson, S. \& Tuna, I. 2007. 'Corporate governance, accounting outcomes, and organizational performance', The Accounting Review, 82: 963-1008.

Levine, R. 1997. 'Financial development and economic growth views and agenda', Journal of Economic Literature, 35: 688-726.

Lin, X. \& Zhang, Y. 2009. 'Bank ownership reform and bank performance in China', Journal of Banking and Finance, 33: 20-29.

Love, I. \& Rachinsky, A. 2007. Corporate governance, ownership and bank performance in emerging markets: Evidence from Russia and Ukraine. World Bank, November. Available [online] http://siteresources.worldbank.org/DEC/Resources/Corporate_Gov ernnace_Ownership_and_Bank_Performance.pdf

Macey, J.R. \& O' Hara, M. 2003. 'The corporate governance of banks', Economic Policy Review, 9: 91-107.

Miller S. \& Noulas, A. 1996. 'The technical efficiency of large banks production', Journal of Banking and Finance, 20: 495-509.

Morgan, D. 2002. 'Rating banks risk and uncertainty in an opaque industry', American Economic Review, 4: 874-888.

Nocera, G., Lannotta, G. \& Sironi, A. 2007. 'Ownership structure, risk and performance in the European banking industry', Journal of Banking and Finance, 31: 2127-2149.

Polo, A. 2007. Corporate governance of banks: The current state of the debate. Munich Personal RePEc Archive Paper No. 2325, Munich University Library.

Prowse, S. 1997. 'Corporate control in commercial banks', Journal of Financial Research, 20: 509-527.

Ramlall, I. 2009. 'Bank-specific, industry-specific and macroeconomic determinants of profitability in Taiwanese banking system: Under panel data estimation', International Research Journal of Finance and Economics, 34: 160-167.

Shan, Y.G. \& McIver, R.P. 2011. 'Corporate governance mechanisms and financial performance in China: Panel data evidence on listed non-financial companies', Asia Pacific Business Review, 17: 301-324.

Short, B. 1979. 'The relation between commercial bank profit rates and banking concentration in Canada, Western Europe and Japan', Journal of Banking and Finance, 3: 209-219.

Sinkey, J. Jr. 1992. Commercial bank financial management in the financial services industry. New York: Macmillan.

Spong, K. \& Sullivan, R.J. 2007. Corporate governance and bank performance. Federal Reserve Bank of Kansas City, 31 August.

Staikouras, C. \& Wood, G. 2003. The determinants of bank profitability in Europe. Proceedings of the European Applied Business Research Conference. Venice: Western Academic Press.

Tarawneh, M. 2006. 'A comparison of financial performance in the banking sector: Some evidence from Omani commercial banks', International Research Journal of Finance and Economics, 3: 101112.

Wei, G. 2007. 'Ownership structure, corporate governance and company performance in China', Asia Pacific Business Review, 13: 519-545.

Wilkins, M.S. 1997. 'Technical default, auditors' decisions and future financial distress', Accounting Horizons, 11: 40-48.

Williams, J. \& Nguyen, N. 2005. 'Financial liberalisation, crisis, and restructuring: A comparative study of bank performance and bank governance in South East Asia', Journal of Banking and Finance, 29: $2119-2154$

Williamson, O. 1985. The Economic Institutions of Capitalism Firms, Markets, Relationship Contracting. New York: Free Press.

Yao, S., Jiang, C., Feng, G. \& Willenbockel, D. 2007. 'WTO challenges and efficiency of Chinese banks', Applied Economics, 39: 629-643. 
